\title{
Treatment Outcomes of Metastatic Colorectal Cancer Patients Treated with Regorafenib as Third-Line Setting-A Multicenter Study
}

\author{
Üçüncü Basamakta Regorafenib ile Tedavi Edilen Metastatik Kolorektal Kanserli \\ Hastaların Sonuçları-Çok Merkezli Çalıșma
}

\author{
(D) Süleyman Şahin11, (1) Muhammet Bekir Hacıoğlu² \\ 1 University of Health Sciences, Van Training and Research Hospital, Clinic of Medical Oncology, Van, Turkey
}

${ }^{2}$ Konya Training and Research Hospital, Clinic of Medical Oncology, Konya, Turkey

\begin{abstract}
Introduction: The clinical benefit of regorafenib therapy in metastatic colorectal cancer (mCRC) patients, who were previously treated with 5-fluorouracil (5-FU), irinotecan, or oxaliplatine based regimens with or without a biologic agent such as vascular endothelial growth factor (anti-VEGF) or anti epidermal growth factor receptor (anti-EGFR), has been shown in several previous phase III studies. In this study, we aimed to analyze the efficacy and toxicity profile of regorafenib in patients with $\mathrm{mCRC}$.

Methods: This was a retrospective study of $23 \mathrm{mCRC}$ patients from two different centers in Turkey. All patients were treated with regorafenib as third line setting after failure of two standard consecutive therapies including 5-FU, irinotecan, or oxaliplatine with or without anti-VEGF or anti-EGFR agent. Treatment outcomes along with drug efficacy and safety were analyzed retrospectively.

Results: Of the 23 patients, 13 were male (56.5\%). Median age was 62 (35-76) years. The rates of RAS wild-type and RASmutated tumor were $43.5 \%$ and $56.5 \%$, respectively. Eighteen patients (78.2\%) received bevacizumab as first-line setting, whereas only five patients (28.8\%) were given a prior anti-EGFR agent. Among the 23 patients, only one patient (4.3\%) had a partial response. Median progression-free survival was 3.02 (2.6-3.37) months and median overall survival was 6.4 (2.610.1) months. There was no prognostic factor associated with survival. Grade 3-4 toxicities were observed in 30.4\% of the patients, with hand-foot skin reaction being the most frequent adverse event (42.8\%).

Conclusion: Although clinical and survival benefits of regorafenib have been demonstrated in previous studies, this advantage seems to be questionable in our study, with a significant toxicity profile making its use challenging. A treatment decision should be made considering the risk of mortality and toxicity profile.
\end{abstract}

Keywords: Metastatic colorectal cancer, overall survival, progression free survival, regorafenib, toxicity

\section{öZ}

Amaç: Daha önce 5-florourasil (5-FU), irinotekan veya oksaliplatin temelli rejimlerle tedavi edilen ve biyolojik ajan olarak vasküler endotelyal büyüme faktörü (anti-VEGF) veya anti epidermal büyüme faktörü reseptörü (anti-EGFR) alan veya almayan metastatik kolorektal kanser (mKRK) hastalarında regorafenib tedavisinin klinik yararı daha önceki faz III çalışmalarında gösterilmiştir. Burada mKRK'li hastalarda regorafenibin etkinlik ve toksisite profilini analiz etmeyi amaçladık.

Yöntemler: Çalışmamızda Türkiye'deki iki farklı merkezden takip edilen 23 mKRK hastasının retrospektif verileri incelenmiştir. Tüm hastalar anti-VEGF veya anti-EGFR ile kombine olarak veya olmaksızın; 5-FU, irinotekan veya oksaliplatin temelli rejimler ile, iki standart ardışık tedavinin bașarısızlığı sonrasında üçüncü basamakta regorafenib ile tedavi edildi. Illaç etkinliği ve güvenliği ile birlikte tedavi sonuçları retrospektif olarak analiz edildi.

Bulgular: Yirmi üç hastanın 13'ü erkekti $(\% 56,5)$ ortanca yaş 62 idi (35-76). RAS wild tip tümör oranı $\% 43,5$, RAS mutant tip tümör oranı ise $\% 56,5$ ti. On sekiz hasta $(\% 78,2)$ birinci basamakta bevasizumab tedavisi almıștı $(\% 28,8)$. Yirmi üç hastanın yalnızca 1'inde $(\% 4,3)$ kısmi yanıt elde edilmiști. Ortanca progresyonsuz sağkalım $3,02(2,6-3,37)$ ay ve ortanca genel sağkalım ise 6,4 (2,6-10,1) aydı. Sağkalımla ilișkili prognostik faktör saptanmadı. En sık yan etki olarak el-ayak sendromu $(\% 42,8)$ görülmekle birlikte, derece 3-4 yan etki \%30,4 hastada saptandı.

Sonuç: Önceki çalışmalarda regorafenibin klinik ve sağkalım yararı gösterilmiş olmasına rağmen, bu avantaj, çalıșmamızda kullanımını zorlaștıran önemli bir toksisite profili ile şüpheli görünmektedir. Mortalite riski ile toksisite profili göz önünde bulundurularak tedavi kararı verilmelidir.

Anahtar Kelimeler: Metastatik kolorektal kanser, genel sağkalım, progresyonsuz sağkalım, regorafenib, yan etki 


\section{Introduction}

Despite recent advances in the treatment of metastatic colorectal cancer (mCRC), it is still the most frequent gastrointestinal system cancer in the western countries, with being an important cause of cancer mortality, affecting approximately 746.000 men and 614.000 women each year (1). Colorectal cancer is the third most common cancer worldwide and the second most common cause of cancer-related deaths in the United States (US), with $20 \%$ to $30 \%$ of patients having synchronous metastatic disease at the time of presentation and more than half of the patients eventually developing metastatic disease with unresectable metastases (2). After the introduction of chemotherapeutic agents such as fluoropyrimidines, oxaliplatine, and irinotecan along with monoclonal antibodies targeting vascular endothelial growth factor (VEGF) or epidermal growth factor receptor (EGFR), median overall survival (OS) duration of $\mathrm{mCRC}$ patients has improved approximately 30 months over the last 20 years (3), with a great extent of this progress being due to molecular targeted therapies, such as anti-angiogenic agents (bevacizumab) or EGFR signaling pathway inhibitors (cetuximab and panitumumab) (4).

Regorafenib, a novel oral multi-kinase inhibitor, has demonstrated antitumor activity in patients with $\mathrm{mCRC}$ who were previously treated with fluoropyrimidine-, oxaliplatine- and irinotecan-based chemotherapy +/- anti-VEGF therapy or anti-EGFR therapy through inhibiting a very diverse range of oncogenic gene products and growth factor receptors including KIT, RET, RAF1, BRAF, BRAFV600E, VEGFR, platelet-derived growth factor receptor PDGFR and fibroblast growth factor receptors (FGFR), hence being approved by FDA 2012 for use as monotherapy as last-line setting $(5,6)$. Anti-tumor activity and survival benefit of regorafenib were previously shown in two large randomized placebo-controlled trials, CORRECT (7) and CONCUR (8), which were performed in $\mathrm{mCRC}$ patients progressing on standard therapies. Survival benefit and efficacy of regorafenib were also confirmed by the large European REBECCA (9) cohort study in a real-world setting, with a similar toxicity profile as seen in previous randomized studies mentioned above.

Here, we performed a multicenter retrospective study to evaluate the efficacy and toxicity profile of regorafenib in mCRC patients in Turkey.

\section{Methods}

From October 2015 to December 2017, a total of 23 consecutive Turkish patients from two major centers receiving regorafenib monotherapy for refractory $\mathrm{mCRC}$ as third-line setting were analyzed. Patients with histologically confirmed mCRC were included in the study. The study was approved by the Necmettin Erbakan University Local Ethics Committee (Decision No. 2018/1319). This retrospective study was designed in accordance with the World Medical Association Declaration of Helsinki "Ethical Principles for Medical Research Involving Human Subjects", amended in October 2013. Since it was a retrospective study, no patient consent form could be obtained. We conducted a retrospective multicenter study to assess the efficacy and toxicity profile of regorafenib in mCRC, patients who were previously treated with fluoropyrimidine-, oxaliplatine- and irinotecan-based chemotherapy +/- anti-VEGF therapy (e.g. bevacizumab, ziv-aflibercept) or anti-EGFR (e.g. panitumumab, cetuximab) when appropriate. Baseline data of all patients, including disease characteristics, patient demographics, laboratory parameters, performance status (PS), treatments, response to treatments, and toxicities were carefully recorded.

After the failure of standard therapies, regorafenib was initiated as a monotherapy at $160 \mathrm{mg}$ daily dose for 21 days with a 28-day repeating cycle. At the discretion of the physicians, a lower initial dose was allowed depending on the patient's clinical condition, and then the dose was increased by $40 \mathrm{mg}$ per week until the maximum dose of 160 $\mathrm{mg}$, relying on the patient's tolerability.

Evaluation of treatment responses was performed every 3 months by computed tomography (CT) or positron emission tomography (PET)CT using the Response Evaluation Criteria in Solid Tumor version 1.1. National Cancer Institute Common Terminology Criteria of Adverse events version 4.0 was used to grade the adverse events. Dose reduction was allowed in case of drug intolerance or $\geq$ grade 3 toxicity. Regorafenib was given until disease progression, unacceptable toxicity or patient's withdrawal.

\section{Statistical Analysis}

All statistical analyzes were performed using Statistical Package for Social Sciences version 21.0 for Windows (SPSS, Inc. Chicago, IL, USA). Descriptive statistics were reported as percentage and median. Survival data were analyzed according to the Kaplan-Meier Method and were compared using Log-rank statistics. P value less than 0.05 was considered as statistically significant. Progression-free survival (PFS) was defined as the period between regorafenib initiation and disease progression or death due to any reason. Overall survival was defined as the period between regorafenib initiation and death due to any cause.

\section{Results}

A total of 23 patients were included in this study. Baseline characteristics are summarized in Table 1. Of the 23 patients, 13 were male (56.5\%). Median age was 62 (35-76) years. The rates of RAS wild-type and RASmutated tumor were $43.5 \%$ and $56.5 \%$, respectively.

Eighteen patients (78.2\%) received bevacizumab as first-line setting, whereas only five patients (28.8\%) were given a prior anti-EGFR agent. The primary tumor was located on the left side in 17 patients (73.9\%). The number of patients who underwent palliative surgery and metastasectomy was nine (39.1\%) and five (21.7\%), respectively. Most of the patients (91.3\%) had a PS of $0-1$ at the beginning of regorafenib therapy.

Regarding survival, median PFS was 3.02 (2.6-3.37) months and median OS was 6.4 (2.6-10.1) months for regorafenib therapy during a median follow-up of 5.4 (2.4-23.4) months (Figures 1 and 2). Overall survival was 37 (23.9-50.4) months. The presence of comorbidity was the only prognostic factor in univariate analysis; however, no factors were found to be associated with survival (Table 2).

Approximately $73.92 \%$ of patients were commenced on lower doses than standard. Starting dose of $160 \mathrm{mg}$ was administered only in six patients. Dose modification was required in $69.56 \%$ of the patients (Table 3). Dose escalation could be performed once in four patients and twice in 
Table 1. Baseline characteristics of patients $(n=23)$

\begin{tabular}{l} 
Number of patients \\
Median age (years) \\
\hline Sex \\
\hline Male \\
\hline Female \\
\hline ECOG performance status \\
$0-1$
\end{tabular}

2

Comorbidity (e.g DM, HT, Atherosclerosis)

No

23 $62(35-76)$

$13(56.5 \%)$

$10(43.5 \%)$

$21(91.3 \%)$

$2(8.7 \%)$

16 (69.6\%)

7 (30.4\%)

Tumor localization

Right

$6(26.1 \%)$

Left

17 (73.9\%)

Palliativesurgery

Yes

9 (39.1\%)

No

14 (60.9\%)

Metastasectomy

Yes

5 (21.7\%)

18 (78.3\%)

RAS mutation status

Mutant

$13(56.5 \%)$

Wild-type

$10(43.5 \%)$

\section{First-line therapy}

Folfox/xelox + Beva

9 (39.1\%)

Folfox/xelox + Pan/Cet

$2(8.7 \%)$

Folfiri + B

$9(39.1 \%)$

Folfiri + Pan/Cet

$3(13.0 \%)$

Response to first-line therapy

Partial response

11 (47.8\%)

Stable disease

$4(17.4 \%)$

Progression

$8(34.8 \%)$

Second-line therapy

Folfox

Folfiri

$2(8.7 \%)$

Folfox/B

$3(13.0 \%)$

Folfox $+\mathrm{C} / \mathrm{P}$

8 (34.8\%)

$1(4.3 \%)$

Folfiri $+B$

$4(17.4 \%)$

Folfiri $+\mathrm{C} / \mathrm{P}$

$3(13.0 \%)$

Other

$2(8.7 \%)$

Response to second-line therapy

Partial response

8 (34.8\%)

Stable disease

$8(34.8 \%)$

Progression

7 (30.4\%)

Response to third-line regorefenib

Partial response

$1(4.3 \%)$

Progression

$22(95.6 \%)$

DM: diabetes mellitus, HT: hypertension

two patients. Dose reduction was required once in seven patients and twice in three patients. Approximately $13.04 \%$ of patients discontinued treatment due to toxicity. The median number of treatment cycles was three (1-11). The most common toxicities of any grade were hand-foot skin reaction (HFSR), fatigue, diarrhea, hypertension, mucositis and thrombocytopenia. Grade 3-4 toxicities were observed in seven patients (30.4\%) with a descending order as follows, HFSR in $42.8 \%$, fatigue in $28.5 \%$, diarrhea in $14.28 \%$ and hypertension in $14.28 \%$ (Table 4).

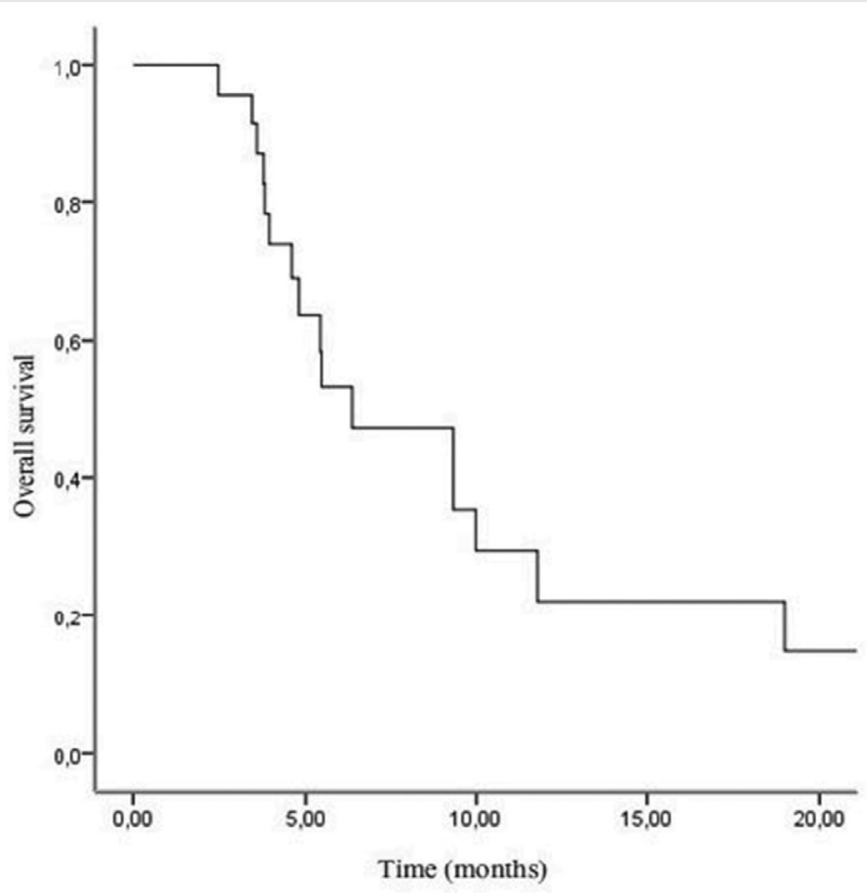

Figure 1. Overall survival curve

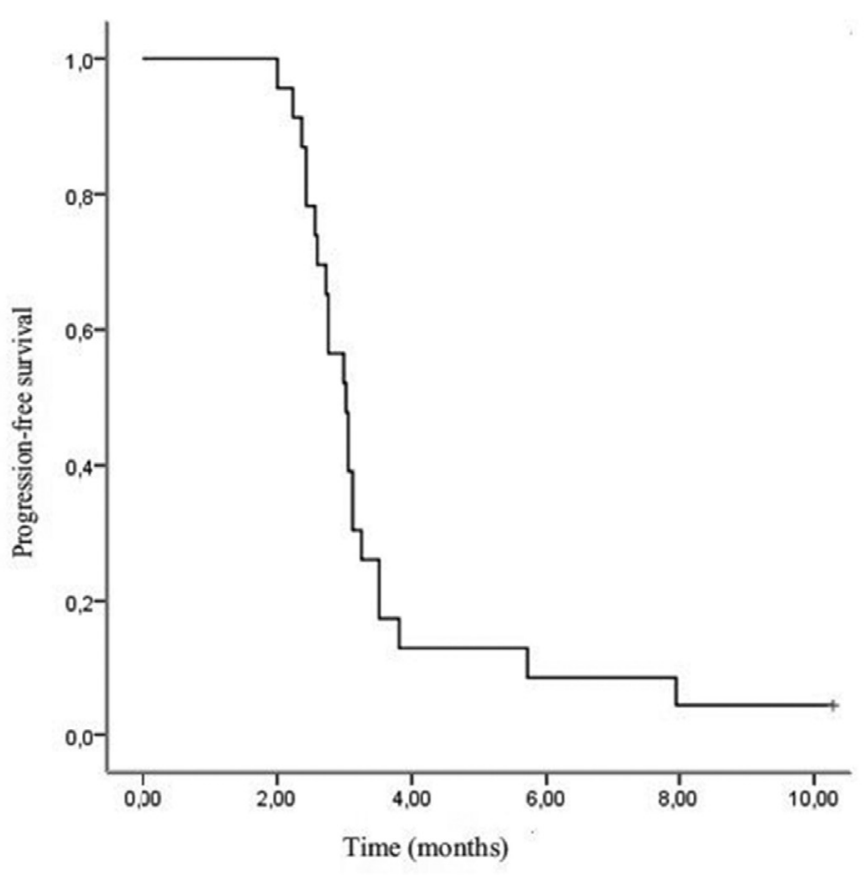

Figure 2. Progression-free survival curve 
Table 2. Univariate analysis

\begin{tabular}{|c|c|c|c|}
\hline Parameters & $n(\%)$ & $\begin{array}{l}\text { Overall survival } \\
\text { (month) } \\
\text { univariate analysis }\end{array}$ & $p$ \\
\hline \multicolumn{4}{|l|}{ Age (years) } \\
\hline$\leq 60$ & $10(43.5)$ & 37.1 & \multirow{2}{*}{0.46} \\
\hline$>60$ & $13(56.5)$ & 32.1 & \\
\hline \multicolumn{4}{|l|}{ Sex } \\
\hline Male & $13(56.5)$ & 45.7 & \multirow{2}{*}{0.12} \\
\hline Female & $10(43.5)$ & 25.7 & \\
\hline \multicolumn{4}{|c|}{ ECOG performance status } \\
\hline $0-1$ & $21(91.3)$ & 41.0 & \multirow{2}{*}{0.20} \\
\hline 2 & $2(8.7)$ & 25.7 & \\
\hline \multicolumn{4}{|c|}{ Comorbidity (DM, HT, Atherosclerosis) } \\
\hline No & $16(69.6)$ & 45.7 & \multirow{2}{*}{$<0.001$} \\
\hline Yes & $7(30.4)$ & 22.3 & \\
\hline \multicolumn{4}{|l|}{ Tumor localization } \\
\hline Right & $6(26.1)$ & 52.4 & \multirow{2}{*}{0.85} \\
\hline Left & $17(73.9)$ & 37.1 & \\
\hline \multicolumn{4}{|l|}{ Palliative surgery } \\
\hline Yes & $9(39.1)$ & 45.7 & \multirow{2}{*}{0.15} \\
\hline No & $14(60.9)$ & 32.1 & \\
\hline \multicolumn{4}{|l|}{ Metastasectomy } \\
\hline Yes & $5(21.7)$ & 45.7 & \multirow{2}{*}{0.69} \\
\hline No & $18(78.3)$ & 32.1 & \\
\hline \multicolumn{4}{|l|}{ RAS mutation status } \\
\hline Mutant & $13(56.5)$ & 45.7 & \multirow{2}{*}{0.24} \\
\hline Wild-type & $10(43.5)$ & 31.7 & \\
\hline \multicolumn{4}{|l|}{ First-line therapy } \\
\hline Folfox/xelox + Beva & $9(39.1)$ & 37.1 & \multirow{4}{*}{0.17} \\
\hline Folfox/xelox + Pan/Cet & $2(8.7)$ & 31.7 & \\
\hline Folfiri + B & $9(39.1)$ & 57.1 & \\
\hline Folfiri + Pan/Cet & $3(13.0)$ & 26.7 & \\
\hline \multicolumn{4}{|c|}{ Response to first-line therapy } \\
\hline Partial response & $11(47.8)$ & 52.4 & \multirow{3}{*}{0.34} \\
\hline Stable disease & $4(17.4)$ & 32.1 & \\
\hline Progression & $8(34.8)$ & 25.7 & \\
\hline \multicolumn{4}{|l|}{ Second-line therapy } \\
\hline Folfox & $2(8.7)$ & 18.1 & \multirow{7}{*}{0.12} \\
\hline Folfiri & $3(13.0)$ & 26.1 & \\
\hline Folfox/B & $8(34.8)$ & 41.0 & \\
\hline Folfox $+C / P$ & $1(4.3)$ & 25.7 & \\
\hline Folfiri + B & $4(17.4)$ & NR not reached & \\
\hline Folfiri $+\mathrm{C} / \mathrm{P}$ & $3(13.0)$ & 37.1 & \\
\hline Other & $2(8.7)$ & 32.1 & \\
\hline \multicolumn{4}{|c|}{ Response to second-line therapy } \\
\hline Partial response & $8(34.8)$ & 45.7 & \multirow{3}{*}{0.01} \\
\hline Stable disease & $8(34.8)$ & 37.1 & \\
\hline Progression & $7(30.4)$ & 23.0 & \\
\hline
\end{tabular}

Table 2. Continued

\begin{tabular}{|l|l|l|l|}
\hline Parameters & $\mathbf{n}(\%)$ & $\begin{array}{l}\text { Overall survival } \\
\text { (month) } \\
\text { univariate analysis }\end{array}$ & $\mathbf{p}$ \\
\hline Response to third-line Regorafenib & & \\
\hline Partial response & $1(4.3)$ & 31.7 & 0.53 \\
\hline Progression & $22(95.6)$ & 37.1 & \\
\hline DM: diabetes mellitus, HT: hypertension & & \\
\hline
\end{tabular}

\section{Table 3. Regorafenib administration}

\begin{tabular}{|l|l|}
\hline Median number or treatment cycles & $3(1-11)$ \\
\hline Starting dose & $\mathbf{n}(\%)$ \\
\hline 160 mgr. & $6(26.08)$ \\
\hline 120 mgr. or lower & $17(73.92)$ \\
\hline Treatment discontinuation & $\mathbf{3}(\mathbf{1 3 . 0 4 )}$ \\
\hline Dose increase & 6 \\
\hline Once & $4(66.6)$ \\
\hline Twice & $2(33.3)$ \\
\hline Dose reduction & 10 \\
\hline Once & $7(70)$ \\
\hline Twice & $3(30)$ \\
\hline
\end{tabular}

Table 4. Adverse events

\begin{tabular}{|l|l|l|}
\hline & $\begin{array}{l}\text { Any grade, } \\
\mathbf{n = 1 8}(\mathbf{7 8 . 2 6} \%)\end{array}$ & $\begin{array}{l}\text { Grade 3-4, } \\
\mathbf{n = 7}(\mathbf{3 0 . 4} \%)\end{array}$ \\
\hline Hand-foot skin reaction & $6(33.3)$ & $3(42.8)$ \\
\hline Fatigue & $4(22.2)$ & $2(28.5)$ \\
\hline Diarrhea & $3(16.6)$ & $1(14.28)$ \\
\hline Hypertension & $2(11.1)$ & $1(14.28)$ \\
\hline Mucositis & $2(11.1)$ & - \\
\hline Thrombocytopenia & $1(5.5)$ & - \\
\hline
\end{tabular}

\section{Discussion}

In the past 10 years, the availability of many drugs and the advent of new anti-angiogenic agents such as bevacizumab combined in standard regimens as first-line, second-line, or beyond progression setting have offered a considerable survival benefit with improved prognosis in patients with $\mathrm{mCRC}$. Angiogenic regulation consists of a range of pathways and inhibition of a single target, such as VEGF, resulting in up-regulation of a diversity of pro-angiogenic factors (10), suggesting that a salvage treatment setting which includes a multi-kinase inhibitor with anti-angiogenic activity may be a plausible treatment option (11). Regorafenib, a novel agent, is a multi-kinase inhibitor targeting a range of receptors including VEGF 1-3, PDGF, tyrosine receptor kinase-2, FGFR, BRAF, KIT, and RET (12).

Here, we aimed to evaluate the efficacy and safety of this new kinase inhibitor, although not including a representative sample. The median OS and median PFS in our study were 6.4 and 3.02 months, respectively. These findings are comparable to those reported in previous randomized studies. The CORRECT study was an international, randomized, and placebo-controlled phase-III trial including 760 patients who were 
randomized 2:1 to receive either regorafenib $160 \mathrm{mg}$ daily or placebo. It demonstrated an improved median OS for regorafenib group compared to the placebo ( 6.4 months vs 5.0 months, $p=0.0052)(7)$, showing similar results to our findings. Another international phase 3 trial, CONCUR, which also confirmed the OS benefit of regorafenib in 204 Asian patients who were randomized 2:1 to receive either regorafenib or placebo (8.8 months vs 6.3 months, $p=0.00016)(8)$, had a better median OS than that observed in our study. Median PFS durations for CORRECT and CONCUR trial were 1.9 and 3.2 months in the regorafenib arm, gaining only 0.2 and 1.5 months, respectively, compared to placebo group. The median PFS in our study was similar to that reported in CONCUR trial and higher than in the CORRECT trial. The REBECCA trial, a cohort of 1178 patients with mCRC, was an open-label and single-arm study of 654 patients (in full analyze) treated with regorafenib after a failure on standard therapies. This study demonstrated a median os of 5.6 months and median PFS of 2.9 months with 12-month survival rate of $22 \%$ (9), indicating a similar median PFS but a lower median OS duration compared to those reported in our study, despite the higher number of patients starting with a lower dose of regorafenib in our study $73.9 \%$ in our study vs $18 \%$ in REBECCA).

The most common toxicities of any grade in our cohort were HFSR, fatigue, diarrhea, hypertension, mucositis and thrombocytopenia. HFSR, fatigue, diarrhea and hypertension were the most common grade 3-4 toxicities. This toxicity profile is substantially consistent with the adverse events reported in the REBECCA real-world cohort (9), CORRECT trial (7), and CONCUR trial (8). Most adverse events were similar in the CONCUR (8) and CORRECT (7) trials, with the only exception of any-grade HFSR (74\% vs $47 \%$, respectively) and impaired liver function tests (37\% vs $20 \%$, respectively), which were more frequent in CONCUR trial (8). The most common reason leading to drug-discontinuation in our study was the toxicity, similar to REBECCA cohort (9). Most of the patients in our cohort (69.56\%) required dose modifications and this was higher than those reported in CORRECT (7) (20\% of patients required a dose reduction) and CONCUR trials (8) (40\% of patients required a dose reduction). Compared to the REBECCA (9) cohort, a larger proportion in cohort started at a lower dose of regorafenib (18\% vs 73,9\%, respectively). Patients should be informed about the prophylaxis and management of regorafenibrelated adverse events prior to treatment to minimize the incidence of adverse events and to ensure that patients take full advantage of regorafenib treatment, thus optimizing treatment outcomes. Therefore, the most common adverse events should be discussed with the patient before the treatment.

The REBECCA real-world analysis (9) reported that high ECOG PS, a shorter time from the initial diagnosis of metastasis, starting at a lower initial dose of regorafenib, more than 3 metastatic sites, the presence of liver metastasis and KRAS mutation were the factors associated with shorter OS. However, there was no predictive factor associated with survival in our cohort, which might be due to the small sample size of our cohort.

So far, some studies have explored some biomarkers of efficacy for regorafenib, but no useful pretreatment biomarker in clinical practice has yet been determined $(13,14)$. Indeed, there is no predictive biomarker to allow the selection of patients most likely to benefit from regorafenib (11). However, Komori et al. (15) reported that serum CA19-
9 response was an early predictive marker of efficacy of regorafenib in mCRC.

The major limitation in our study was the small sample size, resulting in a suboptimal evaluation of outcome predictors in cox regression analysis. Hence, the results of this study should be interpreted with caution. In addition, selection bias and the absence of independent monitoring were other limitations inherent in retrospective studies, which might affect our results. Furthermore, identifying patients who will tolerate full-dose or a reduced dose of regorafenib is pretty important to optimize the study design. Nevertheless, our findings support the available data in the literature and provide useful information regarding the results of mCRC patients treated with regorafenib.

\section{Conclusion}

Regorafenib, a novel agent, is a multi-kinase inhibitor for use as monotherapy at last-line setting in mCRC. Although regorafenib shows a small but significant survival benefit in patients with $\mathrm{mCRC}$ who do not have any further treatment options after the failure over standard therapies, its toxicity profile along with the absence of predictive factors suggest a careful evaluation for the benefit/risk ratio before its use in clinical practice.

Ethics Committee Approval: The study was approved by the Necmettin Erbakan University Local Ethics Committee (Decision No. 2018/1319).

Informed Consent: Since it was a retrospective study, no patient consent form could be obtained.

Peer-review: Externally peer-reviewed.

Author Contributions: Concept - S.Ş.; Design - S.S., M.B.H.; Supervision - S.S., M.B.H.; Resources - S.S.; Data Collection and/or Processing - S.S., M.B.H.; Analysis and/or Interpretation - S.S., M.B.H.; Literature Search S.S.; Writing Manuscript - S.S., M.B.H.; Critical Review - S.S., M.B.H.

Conflict of Interest: No conflict of interest was declared by the authors.

Financial Disclosure: The authors declared that this study received no financial support.

\section{References}

1. Mercier J, Voutsadakis IA. a systematic review and meta-analysis of retrospective series of regorafenib for treatment of metastatic colorectal cancer. Anticancer Res 2017; 37: 5925-34.

2. Abrahao ABK, Ko YJ, Berry S, Chan KKW. A Comparison of regorafenib and TAS-102 for metastatic colorectal cancer: a systematic review and network meta-analysis. Clin Colorectal Cancer 2018; 17: 113-20.

3. Garcia-Alfonso P, Feliu J, Garcia-Carbonero R, Gravalos C, Guillen-Ponce C, Sastre J, et al. Is regorafenib providing clinically meaningful benefits to pretreated patients with metastatic colorectal cancer? Clin Transl Oncol 2016; 18: 1072-81.

4. Hofheinz RD, Arnold D, Kubicka S, Prasnikar N, Vogel A. Improving patient outcomes with regorafenib for metastatic colorectal cancer-patient selection, dosing, patient education, prophylaxis, and management of adverse events. Oncol Res Treat 2015; 38: 300-8.

5. Marks El, Tan C, Zhang J, Zhou L, Yang Z, Scicchitano A, et al. Regorafenib with a fluoropyrimidine for metastatic colorectal cancer after progression on multiple 5-FU-containing combination therapies and regorafenib monotherapy. Cancer Biol Ther 2015; 16: 1710-9. 
6. Kopeckova K, Buchler T, Bortlicek Z, Hejduk K, Chloupkova R, Melichar B, et al. Regorafenib in the real-life clinical practice: data from the czech registry. Target Oncol 2017; 12: 89-95.

7. Grothey A, Van Cutsem E, Sobrero A, Siena S, Falcone A, Ychou M, et al. Regorafenib monotherapy for previously treated metastatic colorectal cancer (CORRECT): an international, multicentre, randomised, placebo-controlled, phase 3 trial. Lancet 2013; 381: 303-12.

8. Li J, Qin S, Xu R, Yau TC, Ma B, Pan H, et al. Regorafenib plus best supportive care versus placebo plus best supportive care in Asian patients with previously treated metastatic colorectal cancer (CONCUR): a randomised, double-blind, placebo-controlled, phase 3 trial. Lancet Oncol 2015; 16: 619-29.

9. Adenis A, de la Fouchardiere C, Paule B, Burtin P, Tougeron D, Wallet J, et al. Survival, safety, and prognostic factors for outcome with Regorafenib in patients with metastatic colorectal cancer refractory to standard therapies: results from a multicenter study (REBECCA) nested within a compassionate use program. BMC Cancer 2016; 16: 412.

10. Kopetz S, Hoff PM, Morris JS, Wolff RA, Eng C, Glover KY, et al. Phase II trial of infusional fluorouracil, irinotecan, and bevacizumab for metastatic colorectal cancer: efficacy and circulating angiogenic biomarkers associated with therapeutic resistance. J Clin Oncol 2010; 28: 453-9.

11. Riechelmann R, Grothey A. The role of regorafenib in metastatic colorectal cancer. The Lancet Oncology 2015; 16: 596-7.

12. Loree JM, Kopetz S. Recent developments in the treatment of metastatic colorectal cancer. Ther Adv Med Oncol 2017; 9: 551-64.

13. Tabernero J, Lenz HJ, Siena S, Sobrero A, Falcone A, Ychou M, et al. Analysis of circulating DNA and protein biomarkers to predict the clinical activity of regorafenib and assess prognosis in patients with metastatic colorectal cancer: a retrospective, exploratory analysis of the CORRECT trial. Lancet Oncol 2015; 16: 937-48.

14. Suenaga M, Mashima T, Kawata $N$, Wakatsuki T, Horiike $\mathrm{Y}$, Matsusaka S, et al. Serum VEGF-A and CCL5 levels as candidate biomarkers for efficacy and toxicity of regorafenib in patients with metastatic colorectal cancer. Oncotarget 2016 7;7: 34811-23.

15. Komori A, Taniguchi H, Hamauchi S, Masuishi T, Kito Y, Narita Y, et al. Serum CA19-9 response is an early predictive marker of efficacy of regorafenib in refractory metastatic colorectal cancer. Oncology 2017; 93: 329-35. 